\title{
Contaminant Baselines and Sediment Provenance along the Puget Sound Energy Transport Corridor, 2015
}

Open-File Report 2018-1196

U.S. Department of the Interior U.S. Geological Survey 
FRONT COVER

Picture of the Burlington Northern Santa Fe rail line on the upper beach in Edmonds, Washington, dated July 2, 2008. Photograph by Renee Takesue, U.S. Geological Survey. 


\section{Contaminant Baselines and Sediment Provenance along the Puget Sound Energy Transport Corridor, 2015}

By Renee K. Takesue and Pamela L. Campbell

Open-File Report 2018-1196 


\title{
U.S. Department of the Interior \\ DAVID L. BERNHARDT, Acting Secretary \\ U.S. Geological Survey \\ James F. Reilly II, Director
}

\author{
U.S. Geological Survey, Reston, Virginia: 2019
}

For more information on the USGS - the Federal source for science about the Earth, its natural and living resources, natural hazards, and the environment—visit https://www.usgs.gov or call 1-888-ASK-USGS (1-888-275-8747).

For an overview of USGS information products, including maps, imagery, and publications, visit https://store.usgs.gov.

Any use of trade, firm, or product names is for descriptive purposes only and does not imply endorsement by the U.S. Government.

Although this information product, for the most part, is in the public domain, it also may contain copyrighted materials as noted in the text. Permission to reproduce copyrighted items must be secured from the copyright owner.

Suggested citation:

Takesue, R.K., and Campbell, P.L., 2019, Contaminant Baselines and Sediment Provenance along the Puget Sound Energy Transport Corridor, 2015: U.S. Geological Survey Open-File Report 2018-1196, 10 p.,

https://doi.org/10.3133/ofr20181196.

ISSN 2331-1258 (online) 


\section{Contents}

Abstract

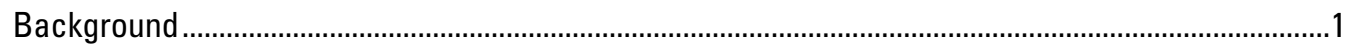

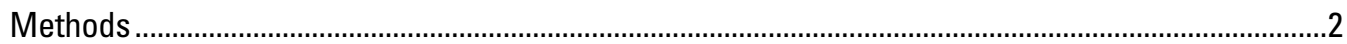

Site Description and Sediment Collection ................................................................................

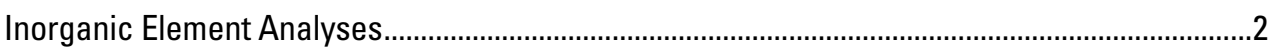

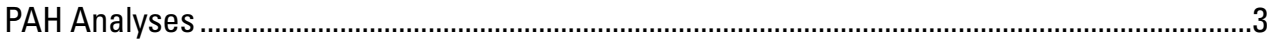

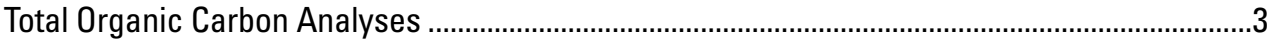

Sediment Quality Criteria ...........................................................................................................

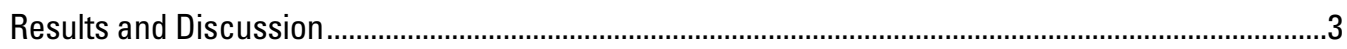

Sediment Quality at Five Nearshore Puget Sound Sites ............................................................

Baseline Sedimentary Contaminants Along the Energy Transport Corridor ..................................4

Elements Elevated at Urban Saltwater State Park ……….............................................................

Sediment Provenance from Rare Earth Element Patterns ............................................................

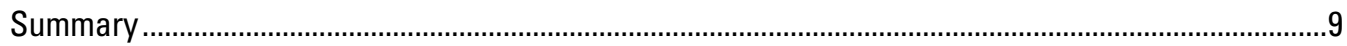

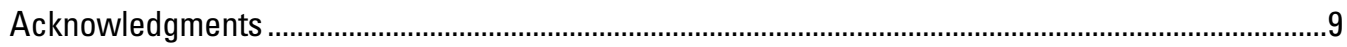

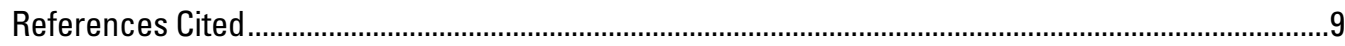

\section{Figures}

1. Satellite imagery map showing the five study sites, Puget Sound, Washington ..................2

2. Graphs showing fine sediment contents of chromium relative to titanium, and nickel relative to magnesium, Puget Sound, Washington ..............................................................

3. Box and whiskers plots of fine sediment arsenic, copper, lead, zinc, mercury, and vanadium contents at Chuckanut Bay, Padilla Bay, Snohomish River Delta, Saltwater State Park, and Nisqually River Delta, Puget Sound, Washington

4. Graphs showing diagnostic polycyclic aromatic hydrocarbon (PAH) ratios calculated from individual PAH values at Chuckanut Bay, Padilla Bay, Snohomish River Delta, and Nisqually River Delta, Puget Sound, Washington.

5. Graphs showing normalized rare earth element patterns in fine sediment from five sites; Chuckanut Bay, Padilla Bay, Snohomish River Delta, Nisqually River Delta, and Saltwater State Park, Puget Sound, Washington.

\section{Tables}

1. Fine sediment contents of potentially toxic elements, total polycyclic aromatic hydrocarbon concentrations, and sediment quality guidelines for nearshore samples, Puget Sound, Washington.

2. Baseline levels of potentially toxic elements, vanadium, and polycyclic aromatic hydrocarbons in sediment along Burlington Northern Santa Fe tracks and at Saltwater State Park, Puget Sound, Washington, September 2015. 


\section{Conversion Factors}

U.S. customary units to International System of Units

\begin{tabular}{|c|c|c|}
\hline Multiply & By & To obtain \\
\hline \multicolumn{3}{|c|}{ Volume } \\
\hline gallon (gal) & 3.785 & liter (L) \\
\hline gallon (gal) & 0.003785 & cubic meter $\left(\mathrm{m}^{3}\right)$ \\
\hline gallon (gal) & 3.785 & cubic decimeter $\left(\mathrm{dm}^{3}\right)$ \\
\hline million gallons (Mgal) & 3,785 & cubic meter $\left(\mathrm{m}^{3}\right)$ \\
\hline
\end{tabular}

International System of Units to U.S. customary units

\begin{tabular}{lcc}
\hline \multicolumn{1}{c}{ Multiply } & \multicolumn{1}{c}{ By obtain } \\
\hline millimeter (mm) & 0.03937 & Length \\
meter (m) & 3.281 & inch (in.) \\
kilometer (km) & 0.6214 & mile (mi) \\
kilometer (km) & 0.5400 & mile, nautical (nmi) \\
meter (m) & 1.094 & yard (yd) \\
\hline & & Volume \\
\hline liter (L) & 33.81402 & ounce, fluid (fl. oz) \\
liter (L) & 2.113 & pint (pt) \\
liter (L) & 1.057 & quart (qt) \\
liter (L) & 0.2642 & gallon (gal) \\
\hline & & Mass \\
\hline gram (g) & 0.03527 & ounce, avoirdupois (oz) \\
\hline
\end{tabular}

Temperature in degrees Celsius $\left({ }^{\circ} \mathrm{C}\right)$ may be converted to degrees Fahrenheit $\left({ }^{\circ} \mathrm{F}\right)$ as ${ }^{\circ} \mathrm{F}=\left(1.8 \times{ }^{\circ} \mathrm{C}\right)+32$.

\section{Supplemental Information}

Concentrations of chemical constituents in sediment are given in milligrams per kilogram $(\mathrm{mg} /$ $\mathrm{kg})$, micrograms per kilogram $(\mu \mathrm{g} / \mathrm{kg})$, micrograms per gram $(\mu \mathrm{g} / \mathrm{g})$, or nanogram per gram $(\mathrm{ng} / \mathrm{g})$.

\section{Datum}

Horizontal coordinate information is referenced to the World Geodetic System standard of 1984 (WGS84). 


\title{
Contaminant Baselines and Sediment Provenance along the Puget Sound Energy Transport Corridor, 2015
}

\author{
By Renee K. Takesue and Pamela L. Campbell
}

\section{Abstract}

The transport of coal and oil can result in contaminated soil, water, and organisms from unintended releases. Trains carrying coal and crude oil regularly pass through Puget Sound, Washington, and an increase in the number of coal and oil trains is expected in the future. This study characterized levels of potentially toxic contaminants in sediment in September 2015: arsenic, metals, and polycyclic aromatic hydrocarbons (PAHs) at four sites with fine-grained sediment (Chuckanut Bay, Padilla Bay, Snohomish River Delta, Nisqually River Delta) adjacent to the Burlington Northern Santa Fe (BNSF) rail line in the Puget Sound region. Arsenic (As) and metals levels were compared to those measured at a fifth site, urban Saltwater State Park, which was expected to show contaminants associated with urbanization but not rail transport of coal and oil because it is not adjacent to the BNSF rail line. Knowledge about current properties of soil and sediment is essential for quantifying impacts of spills and other releases, and for setting remediation or restoration targets. For the sampling effort and timing of this study, all five sites had fine sediment contents of cadmium $(\mathrm{Cd})$, mercury $(\mathrm{Hg})$, lead $(\mathrm{Pb})$, and zinc $(\mathrm{Zn})$ below minimal effects levels. $\mathrm{Pb}$ and $\mathrm{Zn}$ appeared to be urban sourced. Median As, chromium $(\mathrm{Cr})$, copper $(\mathrm{Cu})$, and nickel $(\mathrm{Ni})$ levels were in the range where adverse biological effects would possibly occur; however, $\mathrm{Cr}$ and $\mathrm{Ni}$ were geologically sourced and unlikely to be bioavailable to organisms. $\mathrm{As}, \mathrm{Cu}$, and antimony ( $\mathrm{Sb}$ ) levels were highly correlated, an association that is characteristic of legacy smelting operations; however, total sediment contents of these three elements, along with $\mathrm{Hg}$ and $\mathrm{As} / \mathrm{Sb}$ ratios, were near natural levels and could indicate river-borne inputs. Median total PAH concentrations were highest at Snohomish River Delta, but were below minimal effects levels at all sites Diagnostic PAH ratios were indicative of PAHs sourced from petroleum combustion and coal/biomass burning, rather than from spilled petroleum or coal. Rare earth element patterns were distinct among watersheds with Cascade volcanoes, granitic rocks, or non-volcanic sediments, making them promising sediment provenance indicators. Knowledge about sediment sources and contaminant distributions could provide unique insights about sediment-bound contaminant sourcing, delivery, and dispersal in nearshore regions.

\section{Background}

Coal and oil are transported through Puget Sound, Washington, on rail lines adjacent to marshes, estuaries, and beaches that are important to many species of fish, invertebrates, and birds that use them as nursery habitat, for foraging, or for shelter from predators (Howe and Simenstad, 2015; Rubin and others, 2018; Woo and others, 2018). Coal and oil can be released unintentionally during transport (Lazo and McClain, 1996; Jaffe and others, 2015), and where deposited, they can have direct and indirect adverse effects on health (Lazo and McClain, 1996; Tang and others, 2017). In 2014, railroad companies reported 19 unit trains of Bakken oil moving through Washington State each week, with each unit train made up of as many as 100 cars carrying a total of 3 million gallons of oil (Etkin and others, 2015). This number could increase up to 137 unit trains per week if the full build-out of proposed export facilities is permitted (Etkin and others, 2015). The increased numbers of oil and coal trains passing through the Puget Sound region and larger freight volumes will introduce a greater risk of environmental contamination and spills and adverse effects to organisms. Environmental impact studies and remediation plans related to increased traffic and unintended releases in the Puget Sound energy transport corridor will benefit from knowledge about pre-increase/pre-release, or current baseline, characteristics of soil and sediment. This study characterizes baseline levels of potentially toxic contaminants along the energy transport corridor in four nearshore depositional environments: Chuckanut Bay (northern Puget Sound), Padilla Bay (northern Puget Sound), urban Snohomish River Delta (central Puget Sound), and Nisqually River Delta (southern Puget Sound). A fifth site, Saltwater State Park (central Puget Sound), was included because it is in an urban environment but is not adjacent to the rail line. Target analytes included arsenic (As), potentially toxic metals and polycyclic aromatic hydrocarbons (PAHs) and their diagnostic ratios.

In addition to coal and oil transport, there are many natural and anthropogenic sources, (historical and current) of potentially toxic elements and PAHs to shallow nearshore environments of Puget Sound. These include river-borne and storm water inputs from urban, residential, and agricultural regions (Brandenberger and others, 2008); atmospheric deposition from incomplete combustion processes (that is, fossil fuel burning); creosote-treated wood (Davies and others, 
2012); and historical atmospheric deposits from the ASARCO copper and lead smelter (Crecelius and others, 1975; Bloom and Crecelius, 1987; Louchouarn and others, 2012). Inputs from multiple sources likely contribute to operationally defined contaminant baseline levels in September 2015.

Immobile elements in sediment, or those that are little altered by chemical weathering, erosion, and transport, were explored as sediment provenance indicators. Land-derived sediment delivered to Puget Sound is sourced solely or as mixtures from upland Cascade volcanoes and lowland glacial deposits, and the two sources are expected to have distinct geochemical properties (Takesue and others, 2017). When identified in downstream deposits, these distinct geochemical properties, or signatures, can be used to infer sediment sources, input pathways and timing, and dispersal (McLennan and others, 1993).

\section{Methods}

\section{Site Description and Sediment Collection}

Surface sediment was collected September 14-17, 2015, from four nearshore depositional (fine-grained) environments adjacent to the Burlington Northern Santa Fe (BNSF) rail line in Puget Sound, Washington: Chuckanut Bay, Padilla Bay, the Snohomish River Delta, and the Nisqually River Delta (fig. 1). Sediment was collected from the northern end of Chuckanut Bay, south of the City of Bellingham, in a shallow embayment behind a train trestle. Sediment was collected from the southern end of Padilla Bay in a tidal channel adjacent to the train tracks; Padilla Bay is a National Estuarine Research Reserve and is bounded on the west by March Point, the site of two oil refineries, an oil pier and an oil train spur on the southern and western sides of the bay. Sediment was collected along the banks of the estuarine reach of the Snohomish River Delta near the BNSF Delta Yard and Highway 2 Bridge at the City and Port of Everett. Sediment was collected along the banks of Red Salmon Creek at the Nisqually River Delta where it meanders close to the rail line that borders the Nisqually National Wildlife Refuge to the east. Bluff, beach, and stream bank sediment was collected from Saltwater State Park (fig. 1) on April 22, 2015. Between five and eight field replicates were collected at each site ( 25 samples total); however, not all samples had sufficient fine-grained material for all geochemical analyses. Samples were handled with stainless steel (PAHs) or plastic (inorganic elements) sampling tools and placed into pre-combusted glass jars (PAHs) or plastic wire-top sample bags (inorganic elements). Samples were stored and shipped frozen until analysis.

\section{Inorganic Element Analyses}

Sediment was oven dried at $60^{\circ} \mathrm{C}$ and disaggregated gently with a mortar and pestle to avoid changing grain sizes.
Disaggregated sediment was passed through stainless steel sieves to obtain 2 grams (g) of the less than 63 micrometer $(\mu \mathrm{m})$ fraction, which was sent to the U.S. Geological Survey (USGS) Central Mineral and Environmental Resources Science Center Analytical Chemistry Project, which contracted with SGS Minerals, for determinations of major, minor, and trace elements. Contents of rare earth elements (REE) and

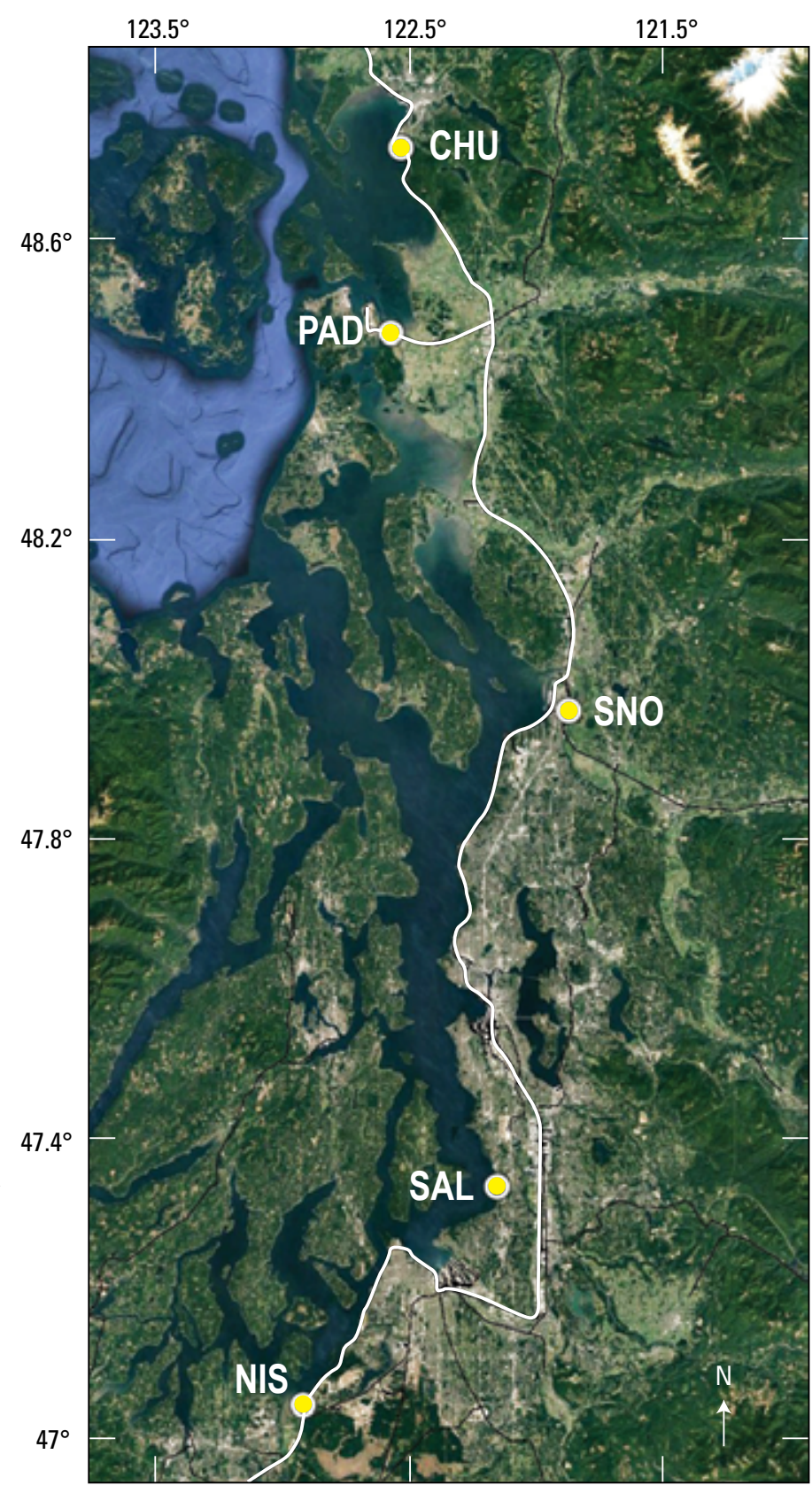

Base map data from Google, 2018

Figure 1. Satellite imagery map showing the five study sites, Puget Sound, Washington. The white line shows the Burlington Northern Santa Fe railroad track. CHU, Chuckanut Bay; PAD, Padilla Bay; SNO, Snohomish Delta; SAL, Saltwater State Park; NIS, Nisqually Delta. 
trace elements in refractory minerals were determined in total sediment digests using a sodium peroxide fusion and analysis by inductively coupled plasma atomic emission spectroscopy (ICP-AES) for major and minor elements, and by inductively coupled plasma mass spectroscopy (ICP-MS) for trace elements (Morrison and others, 2009). Contents of other trace elements were determined in sediment that was subject to a near-total decomposition with a four-acid mixture and analyzed by ICP-MS (Goldhaber and others, 2009). Elemental data were deemed acceptable if recovery of each element in reference materials was \pm 15 percent at 5 times the lower limit of determination. Triplicate analysis of sediment from Padilla Bay yielded a relative standard deviation of 7 percent or less for elements of interest. Total mercury was measured by cold vapor atomic absorption spectrometry (Smith and others, 2009), which has a reporting range from 1 to 100,000 parts per billion. Mercury data were deemed acceptable if recovery in reference materials was \pm 20 percent at 5 times the lower limit of determination. Triplicate analysis of sediment from Padilla Bay yielded a $\mathrm{Hg}$ relative standard deviation of 10 percent.

Sediment contents of potentially toxic elements were compared to aluminum (Al), iron $(\mathrm{Fe})$, magnesium $(\mathrm{Mg})$, and titanium (Ti), which are major constituents of rockforming minerals and indicative of geologic sources, and Sb, a component of emissions from ore smelters and vehicles. Sediment REE contents were normalized to a North American Shale Composite (NASC) of McLennan (1989, table 2). Normalized REE contents are denoted with the letter ' $\mathrm{N}$ '.

\section{PAH Analyses}

Molecular composition of the sedimentary organic fraction was determined by gas chromatography-mass spectrometry (GC-MS) at the USGS Organic Geochemistry Laboratory in Santa Cruz, California. Approximately 1-2 g of freeze-dried organic matter was extracted from bulk sediment by pressurized (accelerated) solvent extraction (ASE, Dionex Corporation, California). Samples were extracted with solvent mixtures of hexane:acetone (1:1) followed by dichloromethane:methanol (2:1). An internal standard (ortho-terphenyl), in addition to surrogate standards (acenaphthene-d10, phenanthrene-d10, chrysene-d12, perylene-d12; ULTRA Scientific), were added to samples prior to extraction. Prior to use, all glassware was washed, solvent rinsed (methanol, hexane, and dichloromethane), and combusted at $450{ }^{\circ} \mathrm{C}$ overnight. Blanks were run for the entire procedure, including extraction, solvent concentration, and purification. After evaporation of extracts to approximately 5 milliliters $(\mathrm{mL})$ volume using a TurboVap Evaporation Concentrator (Zymark Corporation), samples were loaded onto liquid chromatography columns for compound class separation. Each column was layered with $2.5 \mathrm{~g}$ of 5 percent deactivated alumina, $2.5 \mathrm{~g}$ of 62 silica gel, and $5.0 \mathrm{~g}$ of 923 silica gel, which had been previously activated at $500{ }^{\circ} \mathrm{C}$ for 8 hours; and then, in the case of the alumina, partially deactivated with ultrapure water (5 percent water-in-water). Two separate fractions were collected: F1-saturate (100 percent hexane eluent) and, F2-aromatic (30 percent toluene, 70 percent hexane eluent) and reduced in volume under nitrogen gas $\left(\mathrm{N}_{2}\right)$ to $1.0 \mathrm{~mL}$. Extracts were analyzed by splitless injection onto an Agilent 6890 gas chromatograph interfaced to a HewlettPackard 5973 mass spectrometer. The gas chromatograph oven program had an initial temperature of $90^{\circ} \mathrm{C}$, which was held for 4.0 minutes then ramped at $5{ }^{\circ} \mathrm{C}$ per minute to a final temperature of $310^{\circ} \mathrm{C}$ and held at this final temperature for 10 minutes. The capillary column (DB-5MS: 30-meter (m) length, 0.25 -millimeter $(\mathrm{mm})$ inner diameter with a $25-\mu \mathrm{m}$ phase thickness) was directly interfaced to the ion source of the mass spectrometer. Hexane instrument blanks and procedural sample duplicates were done every 10 samples. Compound identifications were made by comparison with known analytical standards or published reference spectra, or both. Concentrations of individual PAHs were calculated from the internal standard. Concentrations (microgram per gram; $\mu \mathrm{g} / \mathrm{g}$ ) are reported normalized to organic carbon (OC) contents. Values of source-indicative diagnostic PAH ratios were obtained from Yunker and others (2002).

\section{Total Organic Carbon Analyses}

Total carbon (TC) and total inorganic carbon (TIC) of bulk sediment were determined coulometrically using a CM5015 Coulometer, a CM5230 furnace, and a CM5130 acid digester (all UIC, Inc.). The total organic carbon (TOC) content was calculated as the difference between TC and TIC.

\section{Sediment Quality Criteria}

Sediment contents of potentially toxic elements and PAHs were compared to sediment quality guidelines for marine and estuarine sediment (Long and others, 1995). The Effects Range-Low (ERL) is a minimal-effects level below which adverse biological effects would be rarely observed. The Effects Range-Median (ERM) is the value above which adverse biological effects would be frequently observed. Sediment with analyte contents between the ERL and ERM are within a possible effects range in which adverse effects would occasionally occur (Long and others, 1995).

\section{Results and Discussion}

Fine-sediment contents of As, potentially toxic metals, and sedimentary PAH concentrations were compared to sediment quality criteria and regionally across the five study sites. Rare earth element patterns characterized sediment provenance. Inorganic element data for individual samples are available online at ScienceBase (Takesue, 2018). 


\section{Sediment Quality at Five Nearshore Puget Sound Sites}

Median fine sediment contents of cadmium (Cd), $\mathrm{Hg}$, $\mathrm{Pb}$, and $\mathrm{Zn}$ for the combined 25 samples from five sites were below the ERL (and ERM) (table 1). Fine sediment Cd contents were close to the analytical reporting limit of 0.1 milligram per kilogram $(\mathrm{mg} / \mathrm{kg})$, and the maximum Cd content $(0.4 \mathrm{mg} / \mathrm{kg}$, Chuckanut Bay) was three times lower than the ERL. For these reasons, $\mathrm{Cd}$ will not be discussed further as a contaminant in these Puget Sound sediments. Median fine sediment contents of As, chromium $(\mathrm{Cr})$, copper $(\mathrm{Cu})$, and nickel (Ni) were between the ERL and ERM (table 1). The elements $\mathrm{Cr}$ and $\mathrm{Ni}$ are known to be elevated in mafic minerals (Lefkovitz and others, 1997) and in such phases are not readily bioavailable. High total $\mathrm{Cr}$ contents were correlated with $\mathrm{Ti}$, and high total $\mathrm{Ni}$ contents were correlated with $\mathrm{Mg}$, indicating that these elements were likely mineral-bound (fig. 2). For this reason, $\mathrm{Cr}$ and $\mathrm{Ni}$ will not be considered further as contaminants in these Puget Sound sediments. Total PAH concentrations were below the ERL (and ERM) when converted to a dry weight basis (table 1).

\section{Baseline Sedimentary Contaminants Along the Energy Transport Corridor}

Baseline levels of potentially toxic elements, vanadium (V) (a component of petroleum and other geologic materials), $\mathrm{As} / \mathrm{Sb}$ ratios, and total $\mathrm{PAHs}$ in sediment are tabulated for each of the four sites along the BNSF rail line and one urban site (table 2). As, $\mathrm{Cu}, \mathrm{Hg}$, and $\mathrm{V}$ had the highest median contents in the Snohomish Estuary (fig. 3). As, $\mathrm{Cu}, \mathrm{Hg}$, and the

Table 1. Fine sediment contents of potentially toxic elements ( 25 samples), total polycyclic aromatic hydrocarbon concentrations (12 samples), and sediment quality guidelines for nearshore samples, Puget Sound, Washington.

[Elements: Sediment concentrations in milligrams per kilogram $(\mathrm{mg} / \mathrm{kg})$ and polycyclic aromatic hydrocarbon (PAH) concentrations were converted to nanograms per gram (ng/g) dry weight (DW) for comparisons with sediment quality guidelines. Effects Range-Low and -Median from Long and others (1995)]

\begin{tabular}{lccccc}
\hline \multicolumn{1}{c}{ Element or Compound } & Minimum & Median & Maximum & $\begin{array}{c}\text { Effects } \\
\text { Range-Low }\end{array}$ & $\begin{array}{c}\text { Effects } \\
\text { Range-Median }\end{array}$ \\
\hline Arsenic & 5 & 8 & 19 & 8 & 70 \\
Cadmium & 0.05 & 0.2 & 0.4 & 1.2 & 9.6 \\
Chromium & 46 & 91.5 & 115 & 81 & 370 \\
Copper & 13 & 36 & 65 & 34 & 270 \\
Lead & 10.1 & 12.5 & 15.5 & 46.7 & 218 \\
Mercury & 0.03 & 0.06 & 0.41 & 0.15 & 0.71 \\
Nickel & 21.5 & 45.3 & 60.4 & 20.9 & 51.6 \\
Zinc & 61 & 89 & 102 & 150 & 410 \\
Total PAHs DW & 11 & 531 & 2,448 & 4,022 & 44,792 \\
\hline
\end{tabular}

\section{$\boldsymbol{A}$}

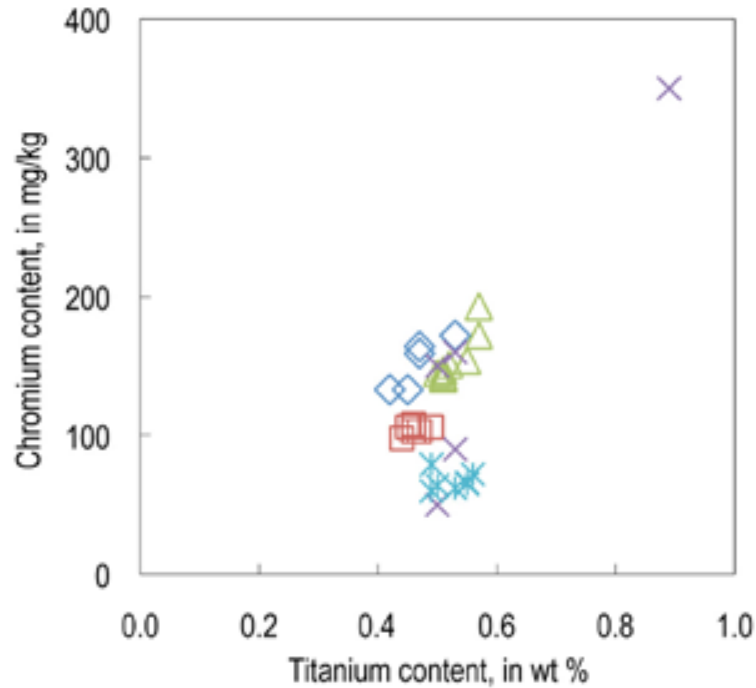

B

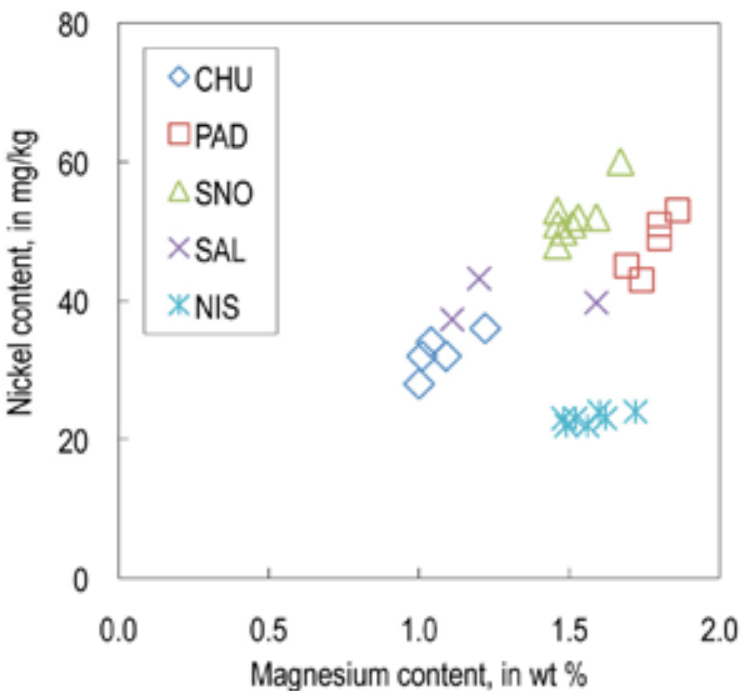

Figure 2. Graphs showing fine sediment contents of chromium relative to titanium $(A)$, and nickel relative to magnesium (B), Puget Sound, Washington. CHU, Chuckanut Bay; PAD, Padilla Bay; SNO, Snohomish River Delta; SAL, Saltwater State Park; NIS, Nisqually River Delta; wt \%, weight percent; mg/kg, milligrams per kilogram. 
Table 2. Baseline levels of potentially toxic elements, vanadium, and polycyclic aromatic hydrocarbons (PAHs) in sediment along Burlington Northern Santa Fe tracks and at Saltwater State Park, Puget Sound, Washington, September 2015.

[All values in milligrams per kilogram $(\mathrm{mg} / \mathrm{kg})$ unless otherwise specified. Polycyclic aromatic hydrocarbon $(\mathrm{PAH})$ concentration units are micrograms per gram organic carbon $(\mu \mathrm{g} / \mathrm{g} \mathrm{OC})$. Abbreviations: CHU, Chuckanut Bay; PAD, Padilla Bay; SNO, Snohomish River Delta; NIS, Nisqually River Delta. n, number of samples; nd, not determined]

\begin{tabular}{|c|c|c|c|c|c|}
\hline Statistic & CHU (n=5) & PAD (n=5) & SNO $(n=8)$ & SAL (n=4) & NIS (n=7) \\
\hline \multicolumn{6}{|c|}{ Arsenic } \\
\hline Mean & 6 & 9 & 16 & 8 & 6 \\
\hline Median & 6 & 9 & 17 & 8 & 6 \\
\hline Minimum & 5 & 8 & 13 & 6 & 5 \\
\hline Maximum & 7 & 10 & 19 & 10 & 7 \\
\hline \multicolumn{6}{|c|}{ Copper } \\
\hline Mean & 15 & 34 & 54 & 36 & 37 \\
\hline Median & 15 & 35 & 52 & 34 & 36 \\
\hline Minimum & 13 & 28 & 50 & 26 & 33 \\
\hline Maximum & 18 & 38 & 65 & 49 & 41 \\
\hline \multicolumn{6}{|c|}{ Lead } \\
\hline Mean & 13 & 13 & 14 & 24 & 14 \\
\hline Median & 13 & 13 & 14 & 23 & 14 \\
\hline Minimum & 11 & 12 & 12 & 10 & 13 \\
\hline Maximum & 14 & 14 & 15 & 42 & 17 \\
\hline \multicolumn{6}{|c|}{ Mercury } \\
\hline Mean & 0.07 & 0.05 & 0.12 & nd & 0.04 \\
\hline Median & 0.06 & 0.05 & 0.08 & nd & 0.04 \\
\hline Minimum & 0.05 & 0.05 & 0.07 & nd & 0.03 \\
\hline Maximum & 0.09 & 0.06 & 0.41 & nd & 0.04 \\
\hline \multicolumn{6}{|c|}{ Vanadium } \\
\hline Mean & 96 & 133 & 143 & 113 & 107 \\
\hline Median & 96 & 133 & 140 & 112 & 106 \\
\hline Minimum & 91 & 124 & 132 & 104 & 102 \\
\hline Maximum & 101 & 141 & 157 & 123 & 113 \\
\hline \multicolumn{6}{|c|}{ Zinc } \\
\hline Mean & 67 & 90 & 98 & 104 & 73 \\
\hline Median & 67 & 90 & 97 & 106 & 73 \\
\hline Minimum & 65 & 84 & 93 & 70 & 70 \\
\hline Maximum & 71 & 94 & 103 & 136 & 76 \\
\hline \multicolumn{6}{|c|}{ Arsenic to Antimony ratio } \\
\hline Mean & 11 & 17 & 15 & 6 & 17 \\
\hline Median & 11 & 15 & 16 & 6 & 15 \\
\hline Minimum & 10 & 14 & 11 & 5 & 13 \\
\hline Maximum & 13 & 21 & 17 & 7 & 21 \\
\hline Statistic & $\mathrm{CHU}(\mathrm{n}=3)$ & PAD (n=3) & SNO (n=2) & SAL & NIS $(n=4)$ \\
\hline \multicolumn{6}{|c|}{ Total PAHs } \\
\hline Mean & 46 & 59 & 99 & nd & 5 \\
\hline Median & 52 & 60 & 99 & nd & 5 \\
\hline Minimum & 20 & 48 & 89 & nd & 4 \\
\hline Maximum & 66 & 68 & 108 & nd & 7 \\
\hline
\end{tabular}



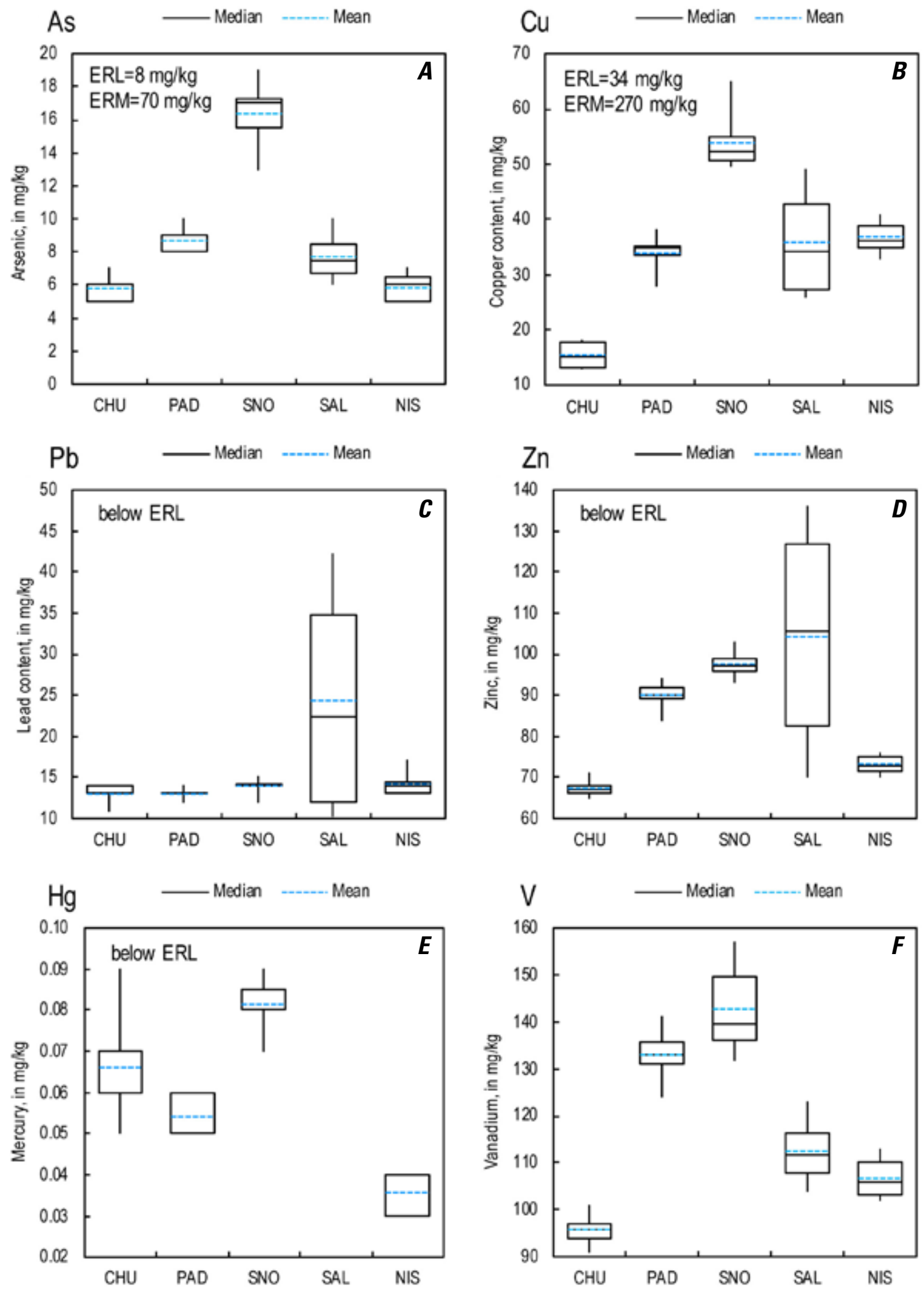

Figure 3. Box and whiskers plots of fine sediment $(A)$ arsenic $(A s),(B)$ copper $(C u),(C)$ lead $(\mathrm{Pb}),(D)$ zinc $(\mathrm{Zn}),(E)$ mercury $(\mathrm{Hg})$, and $(F)$ vanadium $(\mathrm{V})$ contents at Chuckanut Bay (CHU, $n=5)$, Padilla Bay (PAD, $n=5)$, Snohomish River Delta (SNO, n=8), Saltwater State Park (SAL, n=5), and Nisqually River Delta (NIS, n=7), Puget Sound, Washington. Boxes show the first and third quartiles; whiskers show maximum and minimum values. One $\mathrm{Hg}$ outlier was excluded at SNO. Hg was not measured at SAL. ERL, Effects Range Low; ERM, Effects Range Median from Long and others (1995). $\mathrm{mg} / \mathrm{kg}$, milligrams per kilogram. 
element $\mathrm{Sb}$ are known to co-occur at elevated levels in legacy emissions from the copper smelter in Tacoma; however, total sediment contents and $\mathrm{As} / \mathrm{Sb}$ ratios for the energy transport corridor sites (table 2) were within the ranges of natural riverborne sources (Crecelius and others, 1975). Fine sediment V contents were similar to the average continental crust value of $135 \mathrm{mg} / \mathrm{kg}$ (Nriagu, 1998), highly correlated with Fe ( $r=0.78$, $p<0.001, \mathrm{n}=25)$, and therefore not considered to be associated with petroleum transport or refining at the time of this study.

Total sediment PAH concentrations ranged from 4-108 $\mu \mathrm{g} / \mathrm{g}$ OC (11-2448 nanograms per gram (ng/g) dry weight) and median values among the four sites were highest at urbanized Snohomish River Delta and lowest at Nisqually River Delta (table 2). Diagnostic PAH ratios were indicative of PAHs sourced from petroleum combustion (vehicular emissions) and of coal and/or biomass combustion (fig. 4). One sample from Nisqually River Delta had a PAH ratio indicative of a liquid petroleum source, but examination of the low to high molecular weight PAH ratio in this sample indicated a combustion PAH source, so it was excluded from further interpretation.

\section{Elements Elevated at Urban Saltwater State Park}

Saltwater State Park had the highest fine sediment contents of $\mathrm{Pb}$ and $\mathrm{Zn}$ (figs. $3 C$ and $D$ ) and the metalloid, $\mathrm{Sb}$ (not shown), among the five sites, and the co-occurrence of these elements in urban environments is indicative of a vehicular emission source (Sutherland and Tack, 2000).

\section{Sediment Provenance from Rare Earth Element Patterns}

The REE are particularly robust sediment provenance indicators because they are little altered by environmental processes such as soil formation and erosion and sediment transport (Surpless, 2015). Normalized REE patterns at the four Puget Sound energy transport corridor sites had distinct characteristics, and REE patterns at urban Saltwater State Park were most similar to those at Snohomish River Delta (fig. 5). Relatively high values of light REE (LREE), which consist of
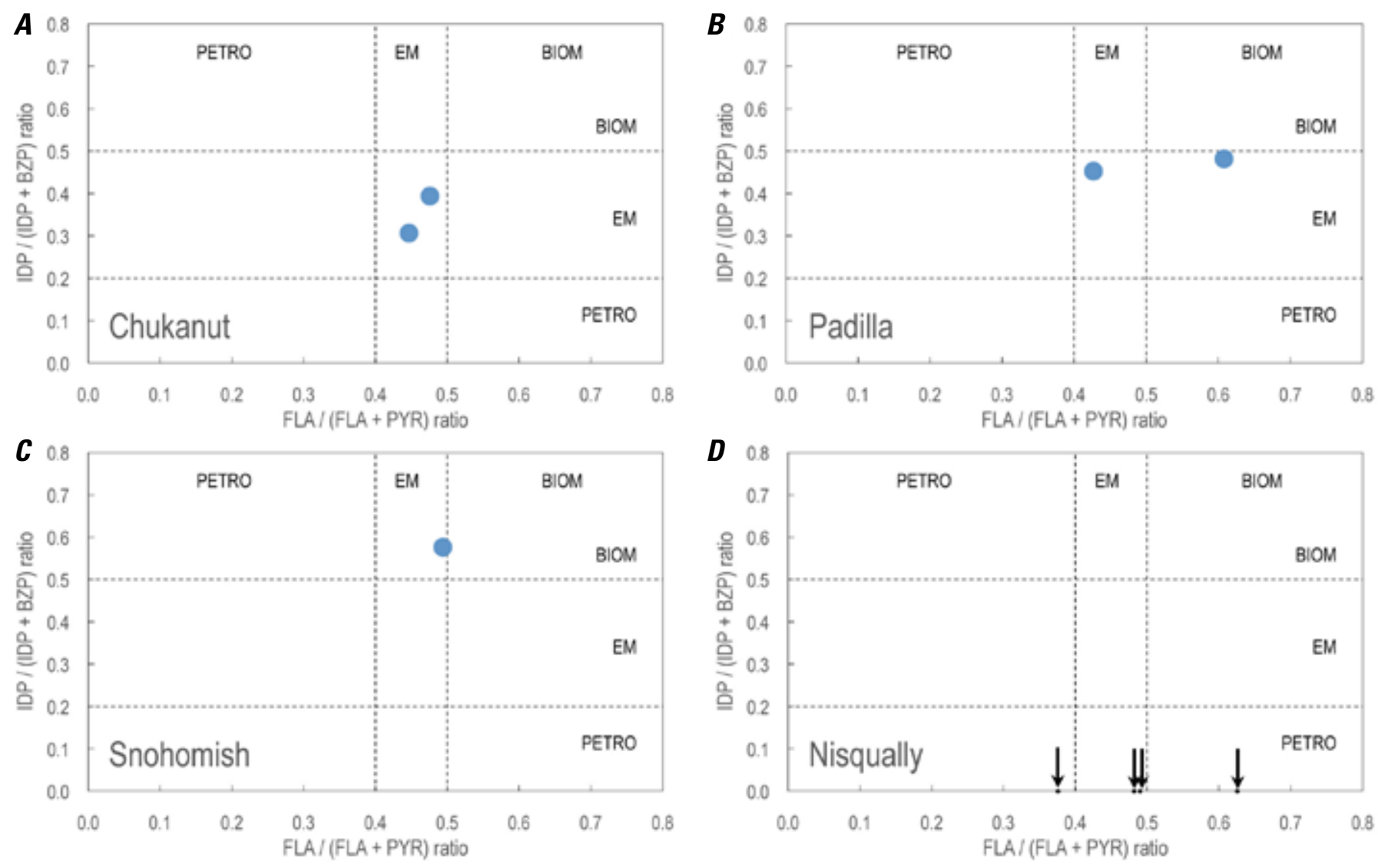

Figure 4. Graphs showing diagnostic polycyclic aromatic hydrocarbon (PAH) ratios calculated from individual PAH values at $(A)$ Chuckanut Bay, $(B)$ Padilla Bay, $(C)$ Snohomish River Delta, and (D) Nisqually River Delta, Puget Sound, Washington. Some individual PAHs were not detected in some samples. IDP, indeno(1,2,3-cd)perylene; BZP, benzo(ghi)pyrene; FLA, fluoranthene; PYR, pyrene. PETRO, petroleum; EM, vehicular emissions; BIOM, biomass combustion. Dashed lines show source-indicative values from Yunker and others (2002). 
lanthanum $(\mathrm{La})$, cerium $(\mathrm{Ce})$, praseodymium $(\mathrm{Pr})$, neodymium $(\mathrm{Nd})$, and samarium $(\mathrm{Sm})$, are indicative of a granitic sediment source at Chuckanut Bay (fig. 5A). The Nisqually River Delta receives sediment from andesitic Mount Rainier volcano, and the sharp and narrow peak around europium (Eu) and relatively low heavy REE contents [HREE, which consist of terbium ( $\mathrm{Tb}$ ), dysprosium (Dy), holmium (Ho), erbium (Er), thulium $(\mathrm{Tm})$, ytterbium $(\mathrm{Yb})$, and lutetium $(\mathrm{Lu})]$ are indicative of felsic volcanic sediment (fig. 5D). Sediment at Padilla Bay originated from the Skagit River, which has tributaries that originate on Mount Baker and Glacier Peak Cascade volcanoes, and also was characterized by a peak around $\mathrm{Eu}$ (fig. $5 B$ ). The broader and lower magnitude Eu peak in Padilla Bay sediment and the slightly higher HREE contents could indicate that non-volcanic sediment mixed with Cascade volcano-sourced sediment in the Skagit River drainage. The central Puget Sound sites Snohomish and Saltwater receive non-volcanic sediment and have REE patterns with an overall positive (upward) slope (figs. $5 C$ and $E$ ), indicative of mafic sediment sources in these drainages. Normalized sediment contents of $\mathrm{Lu}\left(\mathrm{Lu}_{\mathrm{N}}\right)$ relative to $\mathrm{La}\left(\mathrm{La}_{\mathrm{N}}\right)$ for all samples grouped by site (fig. $5 F$ ) indicate that fine-grained Snohomish River Delta and Saltwater State Park sediment had a similar provenance that was different from volcanic-sourced sediment at Nisqually River Delta and Padilla Bay, and from graniticsourced sediment at Chuckanut Bay.

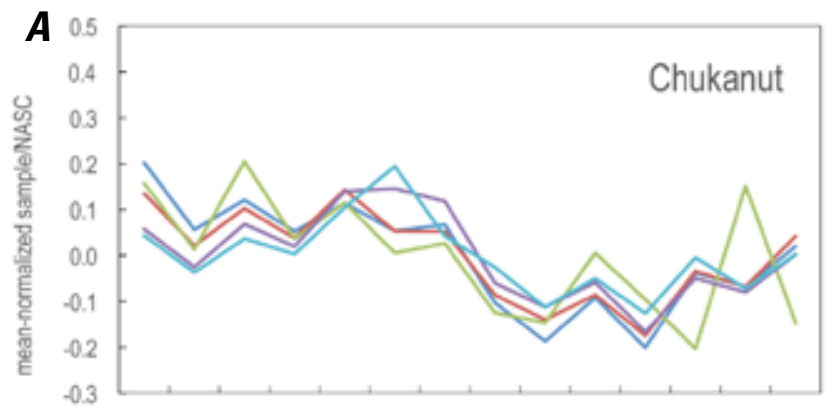

LaN CeN PIN NdN SmN EuN GeN TbN DyN HoN ErN TmN YoN LuN

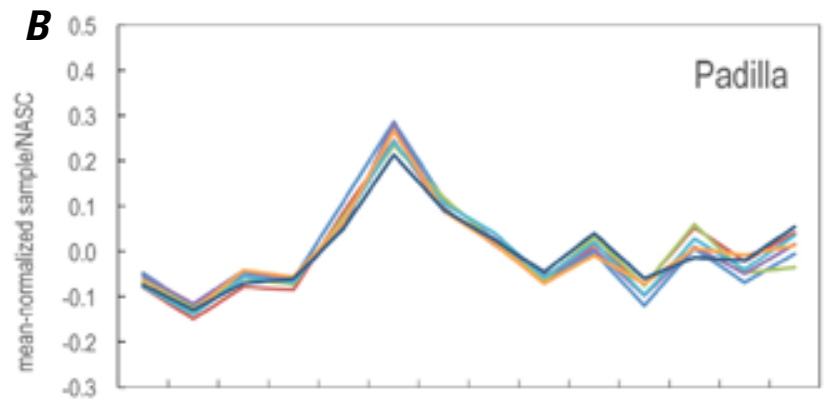

LaN CeN PrN NaN SmN EuN GoN TbN DyN HoN ErN TmN YoN LuN

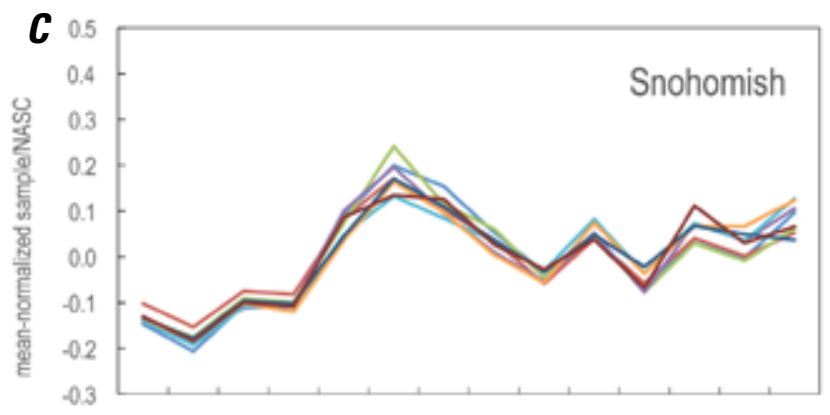

LaN CeN PrN NdN SmN EuN GdN TbN DyN HoN ErN TmN YbN LuN

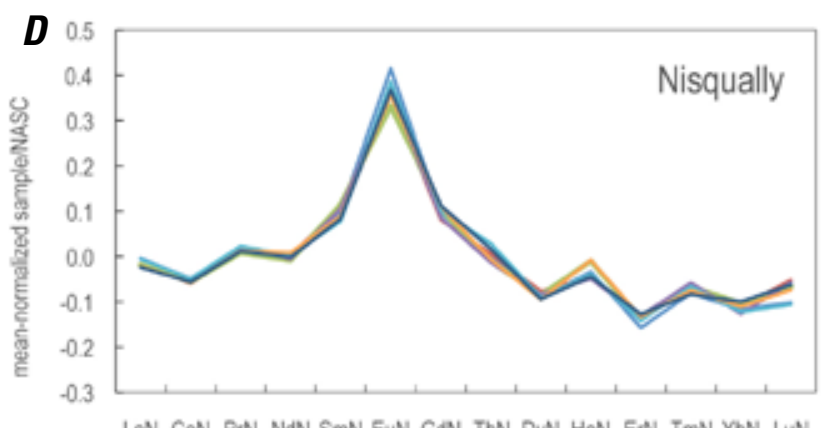

LaN CeN PrN NdN SmN EuN GeN TbN DyN HoN ErN TmN YbN LuN

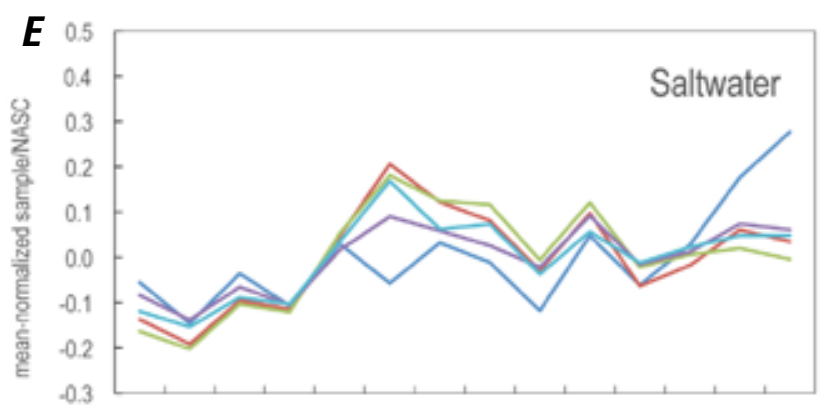

LaN CeN PrN NdN SmN EuN GdN TbN DyN HoN ErN TmN YoN LuN

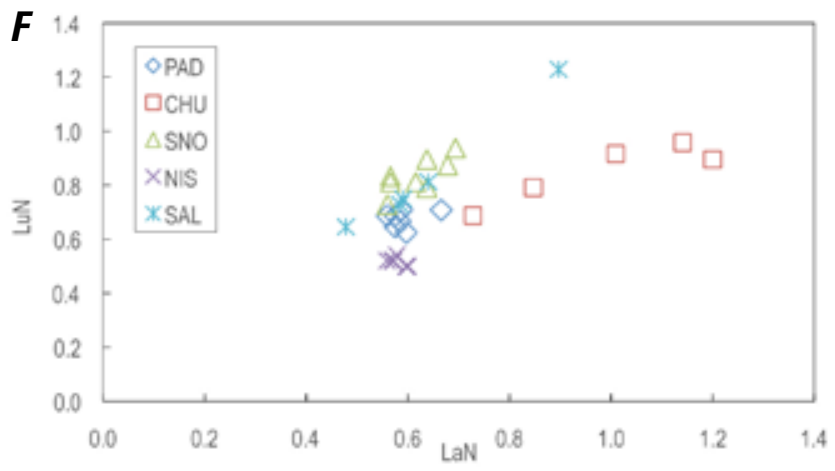

Figure 5. Graphs showing normalized rare earth element patterns in fine sediment from five sites $(A)$ Chuckanut Bay, $(B)$ Padilla Bay, $(C)$ Snohomish River Delta, $(D)$ Nisqually River Delta, and $(E)$ Saltwater State Park, Puget Sound, Washington. Colored lines show individual samples. NASC, North American Shale Composite. La, lanthanum; Ce, cerium; Pr, praseodymium; $\mathrm{Nd}$, neodymium; Sm, samarium; Eu, europium; Gd, gadolinium; Tb, terbium; Dy, dysprosium; Ho, holmium; Er, erbium; Tm, thulium; $\mathrm{Yb}$, ytterbium; Lu, lutetium; $N$, normalized. (F) Graph of normalized fine sediment contents of LuN relative to LaN. PAD, Padilla Bay; CHU, Chuckanut Bay; SNO, Snohomish River Delta; NIS, Nisqually River Delta; SAL, Saltwater State Park. 


\section{Summary}

This study determined baseline levels of arsenic (As), vanadium $(\mathrm{V})$, potentially toxic metals, and polycyclic aromatic hydrocarbons (PAHs) at four nearshore depositional (finegrained) sites along the Puget Sound energy transport corridor in September 2015: Chuckanut Bay, Padilla Bay, Snohomish River Delta, Nisqually River Delta, and at Saltwater State Park, an urban site more than 6 kilometers distant from the Burlington Northern Santa Fe rail line at which urban but not rail transport contaminants were expected to be present. Baselines were quantified to provide context and potential remediation targets for environmental impact assessments and restoration efforts for future rail traffic increase or unintended coal or oil release, or both. For the sites sampled in September 2015, sediment contents of cadmium, mercury (Hg), lead $(\mathrm{Pb})$, zinc $(\mathrm{Zn})$, and total PAHs were low (below a minimaleffects level) and As, chromium (Cr), copper $(\mathrm{Cu})$, and nickel (Ni) were within the range where adverse biological effects would be possible. $\mathrm{Pb}$ and $\mathrm{Zn}$ seemed to be urban-sourced. $\mathrm{Cr}$ and $\mathrm{Ni}$ were geologically sourced and mineral-bound, and therefore unlikely to affect biota. Sediment contents of $\mathrm{As}, \mathrm{Cu}$, $\mathrm{Hg}$, antimony, and $\mathrm{V}$ were within ranges of natural sources and had regional maxima in central Puget Sound. Diagnostic PAH ratios were indicative of vehicle emissions and coal/ biomass burning as sources of PAHs and were highest at Snohomish River Delta. Fine-grained sediments from volcanic watersheds (Mount Baker, Glacier Peak, and Mount Rainier) had distinct rare earth element patterns compared to watersheds with granitic (Chuckanut Bay) and non-volcanic (Snohomish River Delta, Saltwater State Park) sediments. Geochemical provenance indicators could help elucidate sediment and sediment-bound contaminant sources, delivery, and dispersal in nearshore regions.

\section{Acknowledgments}

Funding for this study was provided by the USGS Ecosystems Mission Area and the USGS Coastal and Marine Geology Program. Angela Tan (USGS) and Greg Justin (retired USGS) assisted with field sampling and the USGS Washington Water Science Center provided field support. Leticia Hallas assisted in the Inorganic Geochemistry laboratory. Kathy Conn and Rick Dinicola provided review comments that improved the manuscript.

\section{References Cited}

Bloom, N.S., and Crecelius, E.A., 1987, Distribution of silver, mercury, lead, copper, and cadmium in central Puget Sound sediments: Marine Chemistry, v. 21, no. 4, p. 377-390.
Brandenberger, J.M., Crecelius, E.A., and Louchouarn, P., 2008, Historical inputs and natural recovery rates for heavy metals and organic biomarkers in Puget Sound during the 20th Century: Environmental Science \& Technology, v. 42, no. 18, p. 6786-6790.

Crecelius, E.A., Bothner, M.H., and Carpenter, R., 1975, Geochemistries of arsenic, antimony, mercury, and related elements in sediments of Puget Sound: Environmental Science \& Technology, v. 9, no. 4, p. 325-333.

Davies, H., Stone, A., Grice, J., Patora, K., Kadlec, M., Delistraty, D., Norton, D., and White, J.W., 2012, PAH chemical action plan: Olympia, Washington, Washington State Department of Ecology Publication no. 12-07-048, 241 p.

Etkin, D.S., Joeckel, J., Hayward-Walker, A., Scholz, D., Moore, C., Baker, C., Hatzenbuhler, D., Patton, R.G., Lyman, E., and Culpepper, D., 2015, 2014 Marine and rail oil transportation study: Olympia, Washington, Washington State Department of Ecology, Publication Number 15-08-010, 568 p.

Goldhaber, M.B., Morrison, J.M., Holloway, J.M., Wanty, R.B., Helsel, D.R., and Smith, D.B., 2009, A regional soil and sediment geochemical study in northern California: Applied Geochemistry, v. 24, no. 8, p. 1482-1499.

Howe, E., and Simenstad, C.A., 2015, Using isotopic measures of connectivity and ecosystem capacity to compare restoring and natural marshes in the Skokomish River Estuary, WA, USA: Estuaries and Coasts, v. 38, no. 2, p. 639-658.

Jaffe, D., Putz, J., Hof, G., Hof, G., Hee, J., Lommers-Johnson, D.A., Gabela, F., Fry, J.L., Ayres, B., Kelp, M., and Minsk, M., 2015, Diesel particulate matter and coal dust from trains in the Columbia River Gorge, Washington State, USA: Atmospheric Pollution Research, v. 6, no. 6, p. 946-952.

Lazo, J.K., and McClain, K.T., 1996, Community perceptions, environmental impacts, and energy policy: Energy Policy, v. 24, no. 6 , p. 531-540.

Lefkovitz, L.F., Cullinan, V.I., and Crecelius, E.A., 1997, Historical trends in the accumulation of chemicals in Puget Sound: Silver Springs, Maryland NOAA Technical Memorandum NOS ORCA 111, $60 \mathrm{p}$.

Long, E.R., MacDonald, D.D., Smith, S.L., and Calder, F.D., 1995, Incidence of adverse biological effects within ranges of chemical concentrations in marine and estuarine sediments: Environmental Management, v. 19, no. 1, p. 81-97.

Louchouarn, P., Kuo, L.J., Brandenberger, J.M., Marcantonio, F., Garland, C., Gill, G.A., and Cullinan, V., 2012, Pyrogenic inputs of anthropogenic $\mathrm{Pb}$ and $\mathrm{Hg}$ to sediments of the Hood Canal, Washington, in the 20th Century - Source evidence from stable $\mathrm{Pb}$ isotopes and $\mathrm{PAH}$ signatures: Environmental Science \& Technology, v. 46, no. 11, p. 5772-5781. 
McLennan, S.M., 1989, Rare earth elements in sedimentary rocks - Influence of provenance and sedimentary processes, in Lipin, B.R., and McKay, G.A., eds., Geochemistry and mineralogy of rare earth elements: Washington, D.C., The Mineralogical Society of America, p. 169-200.

McLennan, S.M., Hemming, S., McDaniel, D.K., and Hanson, G.N., 1993, Geochemical approaches to sedimentation, provenance, and tectonics, in Johnsson, M.J., and Basu, A., eds., Processes controlling the composition of clastic sediment: Geological Society of America Special Paper, v. 284, p. 21-40.

Morrison, J.M., Goldhaber, M.B., Lee, L., Holloway, J.M., Wanty, R.B., Wolf, R.E., and Ranville, J.F., 2009, A regional-scale study of chromium and nickel in soils of northern California, USA: Applied Geochemistry, v. 24, no. 8, p. 1500-1511.

Nriagu, J.O., 1998, History, occurrence, and uses of vanadium, in Nriagu, J.O., ed., Vanadium in the environment, Part 1Chemistry and biochemistry: New York, John Wiley \& Sons, Inc., p. 1-24.

Rubin, S.P., Hayes, M.C., and Grossman, E.E., 2018, Juvenile Chinook salmon and forage fish use of eelgrass habitats in a diked and channelized Puget Sound river delta: Marine and Coastal Fisheries, v. 10, no. 4, p. 435-451.

Smith, D.B., Woodruff, L.G., O'Leary, R.M., Cannon, W.F., Garrett, R.G., Kilburn, J.E., and Goldhaber, M.B., 2009, Pilot studies for the North American Soil Geochemical Landscapes Project - Site selection, sampling protocols, analytical methods, and quality control protocols: Applied Geochemistry, v. 24, no. 8, p. $1357-1368$.

Surpless, K.D., 2015, Geochemistry of the Great Valley GroupAn integrated provenance record: International Geology Review, v. 57, no. 5-8, p. 747-766.
Sutherland, R.A., and Tack, F.M.G., 2000, Metal phase associations in soils from an urban watershed, Honolulu, Hawaii: The Science of the Total Environment, v. 256, no. $2-3$, p. $103-113$.

Takesue, R.K., 2018, Inorganic compositional data for fine-grained Puget Sound sediment along the Burlington Northern Santa Fe rail line, September 2015: U.S. Geological Survey data release, https://doi.org/10.5066/ P9JCJ4EQ.

Takesue, R.K., Conn, K.E., and Dinicola, R.D., 2017, Tracking riverborne sediment and contaminants in Commencement Bay, Washington, using geochemical signatures: U.S. Geological Survey Open-File Report 2017-1124, 31 p., https://doi.org/10.3133/ofr20171124, accessed October 30, 2018.

Tang, Z., Chai, M., Cheng, J., Jin, J., Yang, Y., Nie, Z., Huang, Q., and Li, Y., 2017, Contamination and health risks of heavy metals in street dust from a coal-mining city in eastern China: Ecotoxicology and Environmental Safety, v. 138, p. $83-91$.

Woo, I., Davis, M.J., Ellings, C.S., Nakai, G., Takekawa, J.Y., and De La Cruz, S., 2018, Enhanced invertebrate prey production following estuarine restoration supports foraging for multiple species of juvenile salmonids (Oncorhynchus spp.): Restoration Ecology, v. 26, no. 5, p. 964-975.

Yunker, M.B., Macdonald, R.W., Vingarzan, R., Mitchell, R.H., Goyette, D., and Sylvestre, S., 2002, PAHs in the Fraser River basin - A critical appraisal of PAH ratios as indicators of PAH source and composition: Organic Geochemistry, v. 33, p. 489-515. 
Menlo Park Publishing Service Center, California Manuscript approved December 19, 2018

Edited by Carolyn Donlin

Layout by Cory Hurd 
